\title{
New Social Risks in Central and Eastern Europe: The Need for a New Empowering Politics of the Welfare State*
}

\author{
ALFIO CERAMI** \\ Centre for European Studies, Sciences Po, Paris
}

\begin{abstract}
This article examines the economic and social transformation occurring in post-communist societies, with a particular focus on the emergence of new social risks (NSRs) and the subsequent welfare state responses. It argues that Central and Eastern European countries are characterised by broader NSR types (a mix of old and new social risks) and groups than those present in the West. In order to deal more effectively with the requirements of the post-industrial, knowledge-based, and service economy, the reasons for a new political economy of skill formation and for a new empowering politics of the welfare state capable of strengthening the potential of individuals to adapt to more flexible labour markets are discussed. The new empowering politics of the welfare state proposed here would consist of four main pillars: 1) a guaranteed minimum income; 2) a basic income for children; 3) state investments for education and human capital formation; and 4) a guaranteed basic pension. The aim is to empower the individual through de-commodification, childhood investment, human capital formation, and a rebalancing of life risks. The article concludes by reflecting on the political feasibility of this proposal.
\end{abstract}

Keywords: Central and Eastern Europe, social change, welfare state reforms, new social risks, new political economy of skill formation, new empowering politics of the welfare state

Sociologický časopis/Czech Sociological Review, 2008, Vol. 44, No. 6: 1089-1110

\footnotetext{
* Acknowledgements: This article has greatly benefited from discussions with students during a seminar on 'Individual Risks in Post-Industrial Societies' run by the author at the Centre for German and European Studies (CGES) of the State University of Saint Petersburg, Russia. Early concepts elaborated in this article have also been discussed at the Wissenschaftszentrum Berlin für Sozialforschung. The author would like to express his gratitude to Agnes Blome, Eckhard Priller, Jens Alber, Petra Böhnke, Ulrich Köhler and Wolfgang Keck for their valuable comments. The author would also like to thank Pieter Vanhuysse, Jiří Večerník, and the anonymous referees for their valuable recommendations and critical remarks. It goes without saying that whatever faults remain are entirely the responsibility of the author

** Direct all correspondence to: Alfio Cerami, Centre for European Studies, Sciences Po, 224 Boulevard Saint Germain, 75007 Paris, France, e-mail: alfio.cerami@policy-evaluation. org.
}

(C) Sociologický ústav AV ČR, v.v.i., Praha 2008 


\section{Introduction}

Contemporary European societies are undergoing a process of drastic transformation, involving a functional, distributive, normative, and institutional recalibration $^{1}$ [Hemerijck 2008] of the welfare architecture introduced during the trente glorieuses of the welfare state (the period from the 1950s to 1970s). In Central and Eastern Europe, this transformation is even more dramatic owing to the difficult transition from a centrally planned economy to a market economy. Institutional restructuring associated with radical demographic changes, de-industrialisation, and transition to a post-industrial, knowledge-based, and service economy [Liddle and Lerais 2007] are resulting in more severe adaptations of the main political, economic, and social values. In the political sphere, the new principles involve the acceptance of democracy as 'the only game in town' [Linz and Stepan 1996: 5], in the economic sphere, the monetisation of economic relations (citizens are now seen as consumers), and, in the social sphere, the individualisation of responsibilities. New and more diversified social risks are emerging as a consequence.

The literature on new social risks (NSRs) has so far been concerned with Western European countries. A number of authors have identified the principal factors for the emergence of NSRs as the de-industrialisation and tertiarisation of employment, women's entry into the labour market, the increasing instability of the family structure, and processes linked to the privatisation of the welfare state [Esping-Andersen 1999; Esping-Andersen et al. 2002; Taylor-Gooby 2004; Armingeon and Bonoli 2006]. Can such factors, developed for the West, be applied in toto to Eastern Europe, too? Whereas during communism the main risks that Eastern European citizens faced were primarily related to the possibility of not finding necessary consumables in the shops owing to the 'economy of shortage' [Kornai 1992] or dealing with poor or bad quality social services, in the post-communist environment the spectrum of 'new' social risks is substantially broader. NSRs include, for example, balancing paid work with family responsibilities, care for elderly parents, and having a lack of (or obsolete) skills in the labour market as identified for the West. Additionally in Eastern European countries there are the added NSRs of no longer having access to a secure job, a pension, health care, or a minimum income.

The main argument put forward in this article is that Central and Eastern European (CEE) countries are characterised by broader NSR types and groups, and that this societal transformation calls for a new political economy of skill formation [see Vanhuysse 2008a] associated with a new empowering politics of the welfare state, different from the one introduced during the first years of tran-

\footnotetext{
1 The concepts of functional, distributive, normative, and institutional recalibration were first introduced by Ferrera et al. [2000], Pierson [2001], and Hemerijck [2008], to describe the changes that contemporary welfare systems are facing. According to the authors, not only an institutional recalibration is taking place in Western welfare states but also a recalibration of the main welfare functions, aspects of distribution, and basic norms.
} 
sition. The new phase of social modernisation stemming from the fast entry into the knowledge-based economy necessitates, in fact, a drastic change in policy instruments ${ }^{2}$ and political discourses. From status-maintenance policies (the 'old politics of the welfare state') or cost-containment policies (the traditional 'new politics of the welfare state' according to Pierson [2001]), the welfare state in Central and Eastern Europe is now asked to increase its productive function so as to improve its social investment and empowerment capacities.

In order to substantiate this argument, the first part of the article examines several secondary statistics provided by the Eurostat describing the main social changes occurring in Bulgaria, the Czech Republic, Estonia, Hungary, Latvia, Lithuania, Poland, Romania, Slovakia, and Slovenia. The second part briefly discusses the emergence of NSRs and the subsequent responses from the welfare state. Finally, the third part, drawing on the most recent debates on 'skill production regimes' [see Estevez-Abe et al. 2001; Hall and Soskice 2001; Iversen 2005; Iversen and Stephens 2008; Vanhuysse 2008a] and on the 'social investment state' [Esping-Andersen and Palier 2008; Hemerijck 2008], highlights the priorities for a new political economy of skill formation, the core elements of a new empowering politics of the welfare state, and the political feasibility of this proposal.

\section{Social change and the transformation of the social structure in Central and Eastern Europe}

Below, the three main social trends of the transition towards a post-industrial, knowledge-based service economy are briefly highlighted. These include: 1) changes in the labour structure and in employment relations; 2) demographic changes and changes in family and household composition; and 3) the individualisation of responsibilities and the monetisation of economic and social relations.

\section{The labour structure and employment relations}

As far as the changes in the labour structure are concerned, these have primarily involved: i) an increase in the number of unemployed owing to the dismissal of workers in numerous state-owned enterprises; ii) an increase in employment (and in self-employment) in the private sector owing to the privatisation of the centrally planned economy; iii) a drastic decrease in the number of people working in the agricultural and industrial sector only in part covered by an increase in the number of those employed in the service sector; iv) the formation of a new managerial elite (class), formed, however, in large part by previous administrators and technocrats [Eyal et al. 1998]; and v) the emergence of a new middle

${ }^{2}$ On the concept of policy instruments, see the special issue of governance edited by Lascoumes and Le Galès [2007]. 
Table 1. Employment by sector (2006)

\begin{tabular}{lccc}
\hline & Industry & Agriculture & Services \\
\hline Bulgaria & 27.6 & 20.6 & 51.8 \\
Czech Rep. & 37.6 & 3.7 & 58.7 \\
Estonia & 33.1 & 4.9 & 62.0 \\
Hungary & 32.3 & 4.8 & 63.0 \\
Latvia & 27.0 & 11.5 & 61.5 \\
Lithuania & 29.5 & 12.4 & 58.1 \\
Poland & 26.9 & 19.2 & 53.9 \\
Romania & 30.0 & 36.0 & 34.0 \\
Slovakia & 33.8 & 3.6 & 62.7 \\
Slovenia & 35.1 & 9.7 & 55.3 \\
EU 15 & 23.7 & 3.7 & 72.6 \\
\hline
\end{tabular}

Source: DG Employment and Social Affairs [2007: 284-315].

class, including self-employed people who work in their own enterprises, whitecollar workers and intellectuals [György and Róbert 2003].

A more in-depth comparison of employment patterns, as demonstrated by the occupational organisation, shows that CEE societies are now slowly coming closer to the occupational structure of Western countries, though some differences persist. As Table 1 shows, employment in the service sector, though it now accounts for the largest share of employment in all countries, is still far from the EU-15 average (73\%), ranging, with the exception of Romania at $34 \%$, between $50 \%$ and $60 \%$ of the total workforce. The percentages of workers employed in industry, even though drastically diminished since the first years of transition, remains above the EU-15 average (24\%). This is particularly true for the Czech Republic, Estonia, Hungary, Slovakia and Slovenia, where more than one-third of the total workforce is still employed in industry. Also, the percentages of workers employed in the agricultural sector tend to differ from the average of the oldest Western member states (4\%). In this sector, however, there is significant variance within Eastern Europe. The percentages of agricultural workers range from $4 \%$ in the case of the Czech Republic and Slovakia to $36 \%$ in the case of Romania. ${ }^{3}$

Changes in the labour structure have also resulted in changes in employment relations and in particular in: a) the dismissal of life-long employment sta-

\footnotetext{
${ }^{3}$ Please note that the differences in the number of employees in the agricultural sector depend, to a large extent, on the structural differences in employment that existed during communism.
} 
Alfio Cerami: New Social Risks in Central and Eastern Europe

Table 2. Employment and wages

\begin{tabular}{lcccc}
\hline & \multicolumn{2}{c}{ Employment ratio* } & \multicolumn{2}{c}{ Real wages $^{* *}$} \\
& 1989 & 2004 & 1989 & 2004 \\
\hline Bulgaria & 82 & 59 & 100 & 55 \\
Czech Rep. & 87 & 70 & 100 & 137 \\
Estonia & 88 & 71 & 100 & 92 \\
Hungary & 83 & 61 & 100 & 115 \\
Latvia &.. & 70 & 100 & 84 \\
Lithuania & 84 & 67 & 100 & 66 \\
Romania & 77 & 65 & 100 & 120 \\
Poland & 75 & 55 & 100 & 91 \\
Slovakia & 80 & 60 & 100 & 87 \\
Slovenia & 75 & 73 & 100 & 95 \\
EU 15 & 62 & 65 &.. &.. \\
\hline
\end{tabular}

* Employment ratio (number of employed as a percentage of the population aged 15-59).

$* *$ Real wages (index, base year $=100$ ).

Source: TransMonee Database [2008]; Eurostat [2008]; long-term indicators

http://epp.eurostat.ec.europa.eu/.

tus; b) the alteration of the relationship between work performance versus work remuneration; and c) the establishment of new wage gaps. Table 2 shows how the employment ratio (the number of employed as a percentage of the population aged 15-59) has decreased in all CEE countries since the first years of the transition, and, with the exception of Slovenia, is still quite far from the level it was at in 1989. Despite recent economic improvements, real wages (an individual's income after taking into consideration the effects of inflation on purchasing power) have only recently come close to, or surpassed, the level they were at in 1989. The intensity of the increase in real wages has been higher in the Czech Republic, Hungary, and Romania, and lower in Bulgaria, Latvia, Lithuania and Slovakia, where they still correspond to between $50 \%$ and $80 \%$ of the value they were at in 1989 (see Table 2).

In order to have a clearer picture of the differences that exist between East and West, a more detailed analysis of the main groups affected by unemployment is necessary. Table 3 presents interesting results. The total unemployment rate, below the EU-15 average in almost all CEE countries, is still higher in Poland and Slovakia. Similar considerations apply to female, youth, and long-term unemployment, where Poland, Romania, and Slovakia usually stand apart as latecomers. Interesting differences between old and new EU member states exist. In Central and Eastern Europe those citizens who have only primary or basic educa- 
Table 3. Unemployment rates (2007)

\begin{tabular}{lrrrcc}
\hline & Total & Female & 15-24 years & Long-term & $\begin{array}{c}\text { Primary education } \\
(2004)\end{array}$ \\
\hline Bulgaria & 6.9 & 7.3 & 15.1 & 4.1 & 19.8 \\
Czech Rep. & 5.3 & 6.7 & 10.7 & 2.8 & 22.8 \\
Estonia & 4.7 & 3.9 & 10.0 & 2.3 & 15.9 \\
Hungary & 7.4 & 7.7 & 18.0 & 3.4 & 11.0 \\
Latvia & 6.0 & 5.6 & 10.7 & 1.6 & 13.7 \\
Lithuania & 4.3 & 4.3 & 8.2 & 1.4 & 14.0 \\
Poland & 9.6 & 10.4 & 21.7 & 4.9 & 28.4 \\
Romania & 6.4 & 5.4 & 20.1 & 3.2 & 7.2 \\
Slovakia & 11.1 & 12.7 & 20.3 & 8.3 & 48.3 \\
Slovenia & 4.9 & 5.9 & 10.1 & 2.2 & 9.0 \\
EU 15 & 7.0 & 7.8 & 14.7 & 2.8 & 10.1 \\
\hline
\end{tabular}

Source: Eurostat [2008] Structural Indicators. http://epp.eurostat.ec.europa.eu/.

tion are clearly more at risk of unemployment than Western citizens with similar educational attainment.

In addition to the wage gaps that exist between people employed in different occupational sectors and between people of different ages and education levels, there are also wage differences between men and women (the often cited 'gender wage gap'). Once almost non-existent in the region, these wage differences have drastically increased (even though they are still smaller than in most EU member states) [European Commission 2006], with women now facing new forms of gender segregation. This is occurring particularly in Southern European countries (Bulgaria and Romania) and in the Baltic States (Estonia, Latvia, Lithuania), but also in two Visegrád countries (Poland and Slovakia).

\section{Demographic changes}

Demographic changes have also been influenced by the transition, although not in their totality. The decrease in fertility rates coupled with an increase in the number of elderly is slowly resulting in a worsening of the overall dependency ratio with clear consequences for the sustainability of post-communist welfare institutions. The traditional patterns of family formation are also changing. Couples in the region are marrying less and less and the number of children is decreasing, while the divorce rates are growing in almost all countries. These demographic 


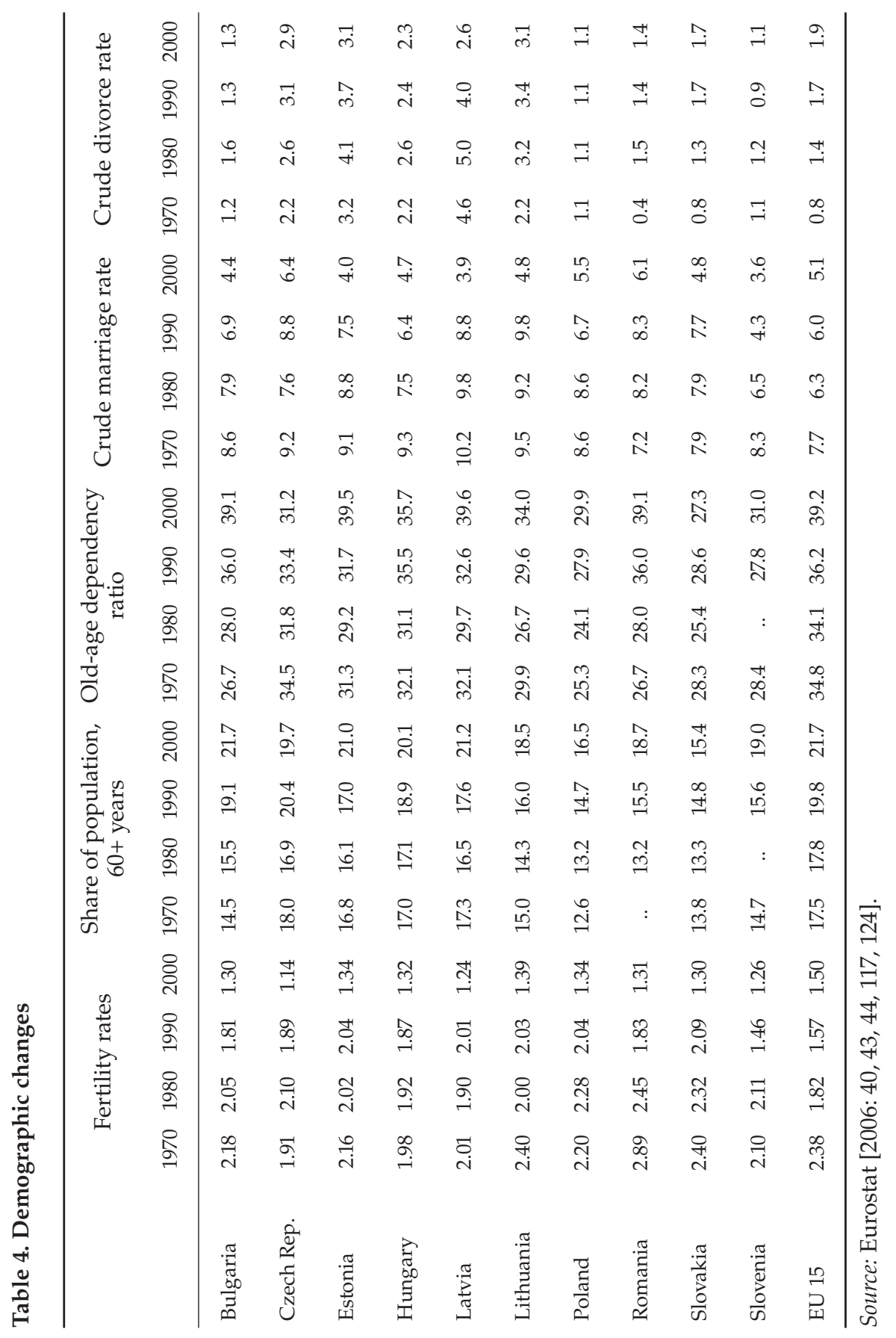


Table 5. At-risk-of-poverty after social transfers (2006) $-60 \%$ of median income threshold

\begin{tabular}{lcccccc}
\hline & Total & Female & $\begin{array}{c}\text { Less than } \\
25 \text { years }\end{array}$ & $\begin{array}{c}65 \text { years } \\
\text { and over }\end{array}$ & $\begin{array}{c}\text { Single } \\
\text { person }\end{array}$ & $\begin{array}{c}\text { Single with } \\
\text { children }\end{array}$ \\
\hline Bulgaria & 14 & 16 & 17 & 18 & 33 & 31 \\
Czech Rep. & 10 & 11 & 13 & 6 & 17 & 41 \\
Estonia & 18 & 20 & 18 & 25 & 42 & 41 \\
Hungary & 16 & 16 & 16 & 9 & 18 & 39 \\
Latvia & 23 & 25 & 21 & 30 & 55 & 40 \\
Lithuania & 20 & 20 & 21 & 22 & 38 & 44 \\
Poland & 19 & 19 & 19 & 8 & 16 & 32 \\
Romania & 19 & 19 & 17 & 19 & 27 & 27 \\
Slovakia & 12 & 12 & 12 & 8 & 17 & 29 \\
Slovenia & 12 & 13 & 9 & 20 & 43 & 22 \\
EU 15 & 16 & 17 & 20 & 20 & 24 & 32 \\
\hline Source: Eur & 19 & 19 & & & & \\
\hline
\end{tabular}

Source: Eurostat [2008]. Structural Indicators. http://epp.eurostat.ec.europa.eu/.

changes, which to a certain extent are similar to those that have been occurring in the West since the 1970s, ${ }^{4}$ require new forms of social protection, which cannot be linked to a relatively stable, dual-earner, life-long employed family that existed during communism.

With regard to the major changes that are occurring in the family and in household composition, they primarily entail increasing poverty for: i) singleheaded households; ii) single parents with children; iii) the young; iv) households with unemployed, part-time, or atypical workers; and v) households of the Roma minority [for a more detailed overview, see World Bank 2005; Cerami 2006]. For these groups of people extreme poverty still represents a major and unresolved problem. As shown in Table 5, different groups of citizens are covered differently by existing welfare institutions. Women are more at risk of poverty in Estonia, Latvia, Lithuania, Poland, and Romania, young people in Latvia and Lithuania, single people in Bulgaria, Estonia, Latvia, Lithuania, and Slovenia, while single people with children are more at risk in the Czech Republic, Estonia, Hungary, Latvia, Lithuania, and Poland. The elderly, by contrast, compared to most of the oldest EU member states, seem to be relatively well-off, especially in the Czech Republic, Hungary, Poland, and Slovakia.

\footnotetext{
${ }^{4}$ Some country and region specifics exist. These include, for example, the bigger decrease in fertility rates and marriages since the transition or the more stable low divorce rates of Catholic Poland.
} 
Poverty, however, is not the only negative outcome, as social segregation is also on the increase [see Böhnke 2005; Fahey et al. 2005], with a higher number of family members from those categories now formally excluded from normal activities that were once available to the society at large (such as access to cultural events). In addition, CEE societies are now characterised by more pronounced forms of social reproduction of inequalities and of intergenerational transmission of poverty than those that existed during communism [Domański 2005; Keller 2005; Profit 2005a, 2005b]. Even though, as has often been highlighted, 'children of disadvantaged class origins have to display far more merit than do children of more advantaged origins in order to attain similar class positions' [Breen and Goldthorpe 1999: 21], the patterns of class reproduction are now much stronger than those that existed before.

\section{The individualisation of responsibilities and monetisation of economic and social relations}

The individualisation of responsibilities and the monetisation of economic and social relations should be mentioned as further key aspects of the social change occurring in post-communist societies. During communism, public responsibility was the main principle regulating all of social life. With the introduction of the market economy things changed and, unfortunately, not always for the better. If, on the one hand, individualisation in the management of social life has given citizens more power to run their own future, then, on the other hand, the economic crisis following the transition has drastically limited the possibilities of the individual's real success. Moreover, a 'recommodification of risks' is also taking place in Eastern societies. Employers are increasingly responding to the volatility of labour, capital, and commodities by transferring market risks to their employees. In Eastern Europe, this process is likely to have more dramatic consequences since citizens have been catapulted into the new reality practically overnight.

Another important feature that has to be mentioned concerns the monetisation of economic and social relations that is now taking place in post-communist societies. The fact that full employment was the rule, that every communist citizen had not only the right but also the obligation to work, and that a wide variety of social services (such as health care, housing, holidays, etc.) were organised directly by the employer meant that money lost much of its appeal. With the advent of the market economy, not only are social and economic relations translated into clear monetary terms (monetised), but the survival of (former) communist citizens is now linked to the successful translation of their skills and work capabilities into marketable goods and services that respond to the fluctuations of demand from markets and not to the decisions of planners. Needless to say, this is a long and very complex process of institutional, cultural, and mental adaptation. 


\section{NSRs and government responses}

The transition from a centrally planned to a market economy coupled with the fast transformation of these CEE societies towards post-industrial, knowledgebased, and service economies has given rise to altogether new risk factors than those present during communism. Nowadays, new forms of social exclusion are emerging as a result of new and different patterns of poverty and income inequality. Uncertain access or entitlement to a pension, health care, employment, basic income, family policies, and educational opportunities are also responsible for exacerbating a situation already made difficult by the negative financial consequences of transition. What is important to remember here is that, even though these can all be addressed as 'old' social risks for Western welfare states, they tend to be new in Eastern Europe. However, difficulties in reconciling labour market flexibility with social and economic security, in balancing work and family responsibilities, and in ensuring care for the elderly, ill, or handicapped parents, the 'new' social risks for Western Europe [Esping-Andersen 1999; Esping-Andersen et al. 2002; Taylor-Gooby 2004; Armingeon and Bonoli 2006; Häusermann and Palier 2007], should also be added to this long list of social challenges. Below, this article looks at the emergence of these new and more diversified social risks and the associated responses from the welfare state.

\section{NSRs in Central and Eastern Europe}

According to Esping-Andersen's classification [1999: 40-43], three different types of social risks can be identified in Western Europe: class-based risks, life-course risks, and intergenerational risks. While class-based risks are primarily concerned with the uneven distribution of risks between social classes, life-course risks involve the uneven distribution of risks over the entire life of the individual. Intergenerational risks, by contrast, are more directly concerned with the intergenerational transmission and inheritance of chances and associated hazards. An example of class-based risks is the threat of unemployment faced by people in poorer social strata owing to their obsolete training and/or skills, whereas life-course risks include growing poverty for the elderly or for younger generations. Finally, intergenerational risks include the possibility that the sons of the unemployed will face a greater chance of becoming unemployed themselves. An alternative, but not very dissimilar model proposed by Kitschelt and Rehm [2006] differentiates NSRs in terms of general existential risks (risks connected with the inability to work owing to illness or old age), group-specific risks I (the obsolescence of skills as a result of structural changes), group-specific risks II (uncertain returns in higher education, e.g. in specific academic fields) and group-specific risks III: demographic risks (loss of earnings as a result of demographic reproduction; for example, raising children).

Regardless of which type of classification is used, an important question 
that still has to be clarified involves the fact of whether these NSR types in the West are similar to the NSR types in Eastern Europe. In fact, although de-industrialisation and the tertiarisation of employment is occurring both in the West and the East, the social changes associated with restructuring the centrally planned economy and the fast emergence of a new social structure no longer based on central planning are phenomena that mainly exist in Eastern European societies. Moreover, while the entry of women into the labour market can be addressed as a possible threat to already existing equilibriums in Western labour markets, this is certainly not the case of post-communist countries, where the employment structure already typically had higher levels of female employment. Instead, as will be seen below, the new challenge that post-communist societies are required to face in this area of social protection, it seems, is not a farewell to maternalism, to use Orloff's expression [Orloff 2006], but rather the establishment of new and different forms of refamilisation, in which women are required to fulfil the social and economic function of wives, mothers, workers, and care-givers in a new and substantially less secure market economy.

In the case of Central and Eastern Europe, in addition to the NSR types that exist in Western societies, there are also specific, 'past-dependent', propertyrelated social risks. They originate in the restructuring of the centrally planned economy and in the subsequent changes occurring in the social structure. Here, the term 'property' should be understood in the broadest possible sense, to include not just material capital (such as the ownership of property assets), but also cultural capital (such as the impossibility of transforming educational skills developed for the communist system into skills that can be used in the post-communist environment), and social capital (such as the capacity to develop or to be part of post-communist social networks) [see Bourdieu 1983].

These distinctions are far from being irrelevant, because in the new, unified, European, knowledge-based society, not only does the competition between people become stronger (the transnational mobility of highly skilled workers from less developed European regions allegedly creates a race to the bottom in terms of wages but also a race to the top in terms of qualifications), but also new and more diversified skills (material, cultural, and social) are required in order to successfully compete in the new economic and social environment.

\section{Government responses to NSRs}

In terms of government responses to old and new social risks, these can, very briefly, be summarised in terms of welfare reforms aiming at: 1) the privatisation of provisions; 2) the individualisation of risks; 3) the monetisation of access; and 4) the decentralisation of management. These four main trends have taken the form of reintroducing (or strengthening) the social insurance principle into the social security system, the privatisation and differentiation of benefits in the pen- 
Table 6. Educational indicators (2007)

\begin{tabular}{lcc}
\hline & $\begin{array}{c}\text { Persons with lowest } \\
\text { education }\end{array}$ & Life-long learning \\
\hline Bulgaria & 22.6 & 1.3 \\
Czech Rep. & 9.5 & 5.7 \\
Estonia & 10.9 & 7.0 \\
Hungary & 20.8 & 3.6 \\
Latvia & 15.0 & 7.1 \\
Lithuania & 11.1 & 5.3 \\
Poland & 13.7 & 5.1 \\
Romania & 25.0 & 1.3 \\
Slovakia & 10.9 & 3.9 \\
Slovenia & 18.2 & 14.8 \\
EU 15 & 32.5 & 11.3 \\
\hline
\end{tabular}

* Percentage of the population aged 25 to 64 having completed at most lower secondary education.

Source: Eurostat 2008. Structural Indicators. http://epp.eurostat.ec.europa.eu/

sion sector, the dissolution of the Semashko health-care model coupled with the introduction of a decentralised public/private mix of health-care facilities, the establishment (in the majority of cases) of a three-pillar system of protection against unemployment consisting of unemployment benefits, unemployment assistance, and social assistance, a redefinition towards the bottom of the excessive benefits and entitlements provided under communism in the family policy sector, and the introduction of a basic safety net for the poorest social strata. This has corresponded with a shift from universalistic to status maintenance aspirations, with resulting increases in poverty and income inequality [see Cerami 2006; OECD 2008].

Additional welfare reforms aimed at targeting NSRs more specifically have also been found in the region. In the employment sector these reforms have taken the form of an increasing use of activation measures; in the family policy sector, a reduction in child care and maternity leaves - associated, however, with the establishment of paternal leave and the first laws for long-term care, ${ }^{5}$ and finally, in the sector of skills improvement, the first attempts at introducing vocational training or life-long learning. The impact of these reforms has varied from country to country, but the results are still far from satisfactory. Taking as a case study the activation policies implemented in the Czech Republic, the best performer

5 Please note that until 1989 long-term care was solely the responsibility of families. When family support was not available, patients were 'institutionalised'. 
among CEE countries, Sirovátka [2006] has, for example, demonstrated that these policies have not always brought the effects they aspired to in terms of increasing employability and reducing long-term unemployment. With regard to the still unresolved problem of balancing work and family responsibilities, in the absence of a coherent policy approach, the measures aimed at reducing excessive child-care provisions and maternity leave do not seem to have been successful in freeing women from their fourfold role of wives, mothers, workers and care-givers. Rather, they seem to have accentuated the demands on women from a pressing labour market; a situation compounded by decreased family stability and poorer household composition [Kwak and Pascall 2005]. Finally, as far as the important issue of improving the obsolete skills of individuals is concerned, Table 6 shows that, even though Eastern Europeans have higher educational attainments than their Western counterparts, they are also less involved in vocational training, or life-long learning, and this in spite of the fact that these two measures would be vital in the process of economic and social transformation.

\section{The new political economy of skill formation and the new empowering politics of the welfare state}

As outlined in the sections of above, the changes in society and the economy associated with the reform of the welfare state have resulted in the emergence of specific NSRs that still need adequate government responses. The following section addresses this issue and discusses why a new political economy of skill formation [see Vanhuysse 2008a] seems to be necessary and what the constituting elements of a new empowering politics of the welfare state could be that would be capable of strengthening the potential of individuals to adapt to more flexible labour markets.

\section{A new political economy of skill formation ${ }^{6}$}

Being successful in the knowledge-based economy requires the development of new and substantially different skills than those promoted during the trente glorieuses of the welfare state. The political economy of skill formation that has characterised the post-war period has been centred on supporting individuals in a stable labour market. Iversen and Stephens [2008] have distinguished three distinct worlds of human capital formation in the post-war Western Europe. The Social Democratic skill production regime has focused on redistribution and heavy investment in public education and industry-specific and occupation-specific vocational skills. The Christian Democratic skill production regime has been

${ }^{6}$ This section greatly benefited from a discussion with Pieter Vanhuysse, to whom the author is greatly indebted. 
oriented towards high social insurance and vocational training in firm-specific and industry-specific skills but less spending on public education. The Liberal regime of skill production typically involves heavy private investment in general skills but modest spending on public education and redistribution. Iversen and Stephens [2008] trace these three worlds to historical differences in the organisation of capitalism, electoral institutions, and partisan politics, emphasising not just the distinct character of political coalition formation behind each of the three models, but also the different performances in terms of inequality and labour market stratification. The authors' analysis does not include the Communist skill production regime, but arguably its key characteristics would resemble those of Social Democratic skill production, with high redistribution and heavy investment in public education, and an overemphasis on industry-specific compulsory skills at the expense of non-strategic occupational skills. Consequently, in the Communist skill production regime, market stratification was characterised by an abnormal homogeneity in human capital formation, which was able to sustain the economy while ensuring relatively low levels of social inequality only through the redistributive capacity of central planning.

By contrast, in the new post-industrial, knowledge-based, and service economy, not only a well-educated, better-trained, more diversified, and serviceoriented work-force is necessary, but individuals are also called on to adapt to more flexible and less secure labour markets. A constant increase in atypical or non-standard forms of work, with the associated increasing wage gaps, is a reality that can no longer be concealed. As highlighted by the recent OECD report Growing Unequal, not just GDP has grown in advanced industrialised economies since the 1980s, but new forms of poverty and income inequality have also been rising [OECD 2008]. As discussed in more detail below, this imbalance between economic growth and redistribution in a different market environment calls for a new politics of social security, which has to be associated with a new, more systematic and better adapted political economy of skill formation [see Vanhuysse 2008a] capable of improving the learning skills and adaptation of individuals to the new labour market requirements. In fact, if Iversen and Stephens' [2008] considerations were applied to the Post-communist skill production regime, then the result would be a hybrid regime made of an unclear mix of the four models mentioned above (high social insurance, modest public investments in education, increasing reliance of private investments in industry-specific and occupationspecific skills coupled with high distributive aspirations but growing levels of social inequality), but still not suited for the new post-communist environment.

With respect to the changes occurring in household and family composition, new and different forms of human capital, no longer based on traditional family patterns, should also be developed. The assumption of stable couples with long-term and secure jobs is no longer valid, and the increase in single-headed households, divorces, women working part-time, and young people with atypical jobs demand new means of integration through new public policy instru- 
ments and through the development of new and more suitable skills. Households with NSR groups are more at risk of poverty and income inequality, and new and more severe forms of social reproduction of poverty and inequalities, with the subsequent transmission of poverty to children, are also on the rise. In this context, child poverty, a major problem in all Western economies [see OECD 2008], but also in CEE countries [see LIS Key Figures 2008], has several harmful effects. Children from poor families experience not only more difficulties at school but also more difficulties in later stages of life, such as difficulties finding a well-paid job in an ever more demanding labour market or difficulties connected with social inclusion or achieving personal happiness. In this context, improving the human capital and income status of parents is a crucial response in order to reduce the negative effects of the social reproduction of poverty [Heckman and Krueger 2003; Esping-Andersen 2007, 2008].

Finally, with regard to the individualisation of responsibilities and risks, a new political economy of skill formation would seem a necessary precondition for dealing more successfully with the increased demands stemming from deregulated labour markets. Here, fostering the independence and autonomous integration of individuals in society as a whole should be seen as a policy priority, while the development of human capital (especially social and cultural capital) should constitute a key element of policy in order to bring people out of poverty [Sirovátka and Mareš 2008].

\section{The new empowering politics of the welfare state}

A new political economy of skill formation is in this context an essential prerequisite if CEE citizens are to adapt to the requirements of the knowledge-based society, but this is still not enough to ensure adaptation and coverage in a substantially different and more insecure labour market. Also important is the introduction of 'new empowering politics' into the welfare state. Welfare policies are useful for helping people out of extreme poverty, but they also fulfil an important function as 'institutional complementarities' [Hall and Soskice 2001] of the capitalist system. By providing education and training in those sectors of the economy where private investments would be too expensive and less remunerative, they help, for example, employers to find an adequately trained work force in the labour market [Estevez-Abe et al. 2001; Hall and Soskice 2001; Iversen 2005; Iversen and Stephens 2008; Vanhuysse 2008a]. However, a redefinition of the main redistributive priorities of the welfare state is necessary and with it a recalibration of its main norms, institutional structures, and functions [Hemerijck 2008]. This clearly means the introduction of new and more specific policy instruments and political discourses.

At a more practical policy level, linking the debate on 'skill production regimes' [see Estevez-Abe et al. 2001; Hall and Soskice 2001; Iversen 2005; Iversen and Stephens 2008; Vanhuysse 2008a] to the debate on the 'social investment 
state' [see Atkinson 2002; Esping-Andersen and Palier 2008; Hemerijck 2008; Hinrichs 2008; Vanhuysse 2008a], it is possible to envisage four core elements in the new empowering politics of the welfare state. These four pillars would correspond to: 1) a guaranteed minimum income for vulnerable groups in society; 2) a basic income for children; 3) state investments for education and human capital formation; and 4) a guaranteed tax-financed basic pension coupled with an earnings-related account for the elderly. With regard to the first pillar, leaving aside the debate of whether a minimum subsistence level should be provided to all citizens regardless (i.e. a basic income) or after means-testing (guaranteed minimum income), ${ }^{7}$ the establishment of minimum income schemes seems to be an important policy instrument, which on the one hand can protect the most vulnerable groups in society from poverty and income inequality, and on the other hand can provide them with a concrete opportunity for self-advancement. In contrast to the 'old politics of the welfare state', the main goal here would be not simply to shield citizens from the effects of the temporary negative performance of markets (a poverty alleviation strategy), but rather to detach individuals from the risks associated with more deregulated, less protective and redistributive labour markets. To put it clearly, in this pillar, the welfare state's new empowering politics would empower through de-commodification [see Esping-Andersen 1990; Atkinson 2002]. The second pillar of the new empowering politics could consist of a basic income for children to protect them from increasing poverty, while enabling parents to invest more time in the labour market and in their children's development [see Esping-Andersen 2008]. In this pillar, empowerment is achieved through childhood investment. The third pillar of the new empowering politics of the welfare state should, as a consequence, consist of measures aimed at increasing the human capital of citizens through state investments in education and human capital formation. This would not only be beneficial to individuals, to help them cope with the individualisation and monetisation of risks in a more effective manner, but would also generate new and more suitable skills to be employed in the knowledge-based economy [see Esping-Andersen 2007; Esping-Andersen and Palier 2008; Hemerijck 2008]. In this pillar, empowerment is achieved through human capital formation. Finally, the fourth pillar of the welfare state's new empowering politics would consist of a basic income pension, tax financed and available on a universal basis, and associated with an earnings-related account (eventually privately managed) for the working population. This scheme would ensure professional diversity at the top of the income classes, and it would also redistribute life risks in a more balanced way through the entire course of an individual's existence (for an interesting analysis, see Hinrichs [2008]). In this pillar, empowerment is derived from the rebalancing of life risks. Are these new empowering politics a feasible political option for the welfare state?

\footnotetext{
7 This is certainly not an irrelevant distinction, but it goes beyond the scope of this paper. For more information on the key characteristics of basic income, see documents available at Basic Income Earth Network http://www.basicincome.org/bien/.
} 
Alfio Cerami: New Social Risks in Central and Eastern Europe

The new empowering politics of the welfare state, political coalitions and voter preferences

In order to make the new empowering politics a feasible option, the main logic in social policy needs to be reconsidered. In the knowledge-based economy, social policy spending can no longer be seen as a burden to economic development, but rather as an investment aimed at improving adaptation to the labour market. Returns from this type of 'social investment' would in fact be extremely large [Esping-Andersen and Palier 2008; Hemerijck 2008]. For example, as argued by Esping-Andersen and Palier [2008], workers better adapted to the labour force could ultimately pay more overall in taxes, the labour market could draw on a better-trained workforce, and the productivity of employees would increase.

In terms of voter preferences, the introduction of the new empowering politics would also be a viable option, provided that new political discourses [Schmidt 2008] are developed. In fact, as highlighted by Iversen [2005] and Vanhuysse [2008a], welfare policies aiming at producing new skills and at targeting thus far unprotected groups of citizens can be profitable for individuals, firms, markets, and even politicians. In European history (but also elsewhere), not only has skill specificity (together with income the best predictors of voter preferences on welfare issues) resulted in the formation of particular political coalitions, but these have also in many cases been able to influence party politics on specific issues (e.g. pensioners' associations, or blue-collar or atypical workers) [Bonoli 2007]. CEE societies have so far been characterised by less effective union elites and less politically mobilised NSR groups than those present in the West [Ost 2005; Vanhuysse 2006, 2007, 2008b]. But this does not necessarily mean that the requests coming from these groups of citizens will diminish or that they will continue to have little impact on future welfare state reforms. An emblematic example of how NSR constituencies can block reforms is provided by the protests in the Russian Federation following Putin's attempts to replace in-kind benefits with cash benefits (the 'monetisation' of benefits). These protests were started in the streets of Moscow and St. Petersburg in January 2005 by associations of pensioners and poor income groups, and resulted, a few weeks later, in unprecedented obstruction in the Duma [Cerami 2009]. In the eyes of many observers, these protests and obstruction in the Duma were in fact to be expected, since these reforms would have substantially reduced the role of the Russian welfare state, especially as benefiting the most vulnerable categories. The formation of NSR coalitions was therefore the predictable outcome of tabling policies targeting specific categories of previously unheard of constituencies.

\section{Conclusion}

This article highlighted the drastic economic and social changes that have been occurring in post-communist societies. It was argued that the fast transformation 
of CEE societies towards becoming post-industrial, knowledge-based, service economies has resulted in the emergence of completely new factors of risks than those present during communism. New forms of social exclusion have emerged as a result of new and different patterns of poverty and income inequality. Uncertainties surrounding pensions, health care, employment, basic income, family policies and educational opportunities have compounded a situation already made difficult by the negative economic consequences of transition. For Western welfare states these are the 'old' social risks that must be dealt with, but in Eastern Europe they must be regarded as new. The already long list of social risks in CEE societies, involving difficulties in reconciling labour market flexibility with social and economic security, in balancing work and family responsibilities, and in ensuring care for the elderly, the ill, or handicapped parents, has grown with the emergence of the 'new' social risks typical for Western Europe.

Government responses to old and new social risks in the form of welfare reforms aimed at privatising welfare provisions, individualising risks, and monetising access to benefits, while decentralising the management of the social security system, do not seem to have properly addressed the problems that Eastern European citizens are facing. This is primarily because of the existence of a political economy of skill formation particularly suited for the 'golden age' of the welfare state and centred on supporting individuals in a stable labour market. In the new post-industrial, knowledge-based, service economy, not only a well-educated, better trained, more diversified, and service-oriented work-force is necessary, but individuals are also called on to adapt to more flexible and less secure labour markets.

So far, the political economy of skill formation that has characterised the post-communist transition (the Post-communist skill production regime) has been characterised by an ambiguous mix of high social insurance premiums, modest public investments in education, and the increasing reliance on private investments into industry-specific and occupation-specific skills, associated, however, with high distributive aspirations but growing levels of social inequality. A new political economy of skill formation would, in this context, represent a useful policy instrument, but this would still not be enough to ensure adaptation and coverage in a substantially different and more insecure labour market. The introduction of a new empowering politics of the welfare state is also important here. Welfare policies are crucial for protecting people from poverty and they represent important institutional complementarities [see Hall and Soskice 2001] of the capitalist system.

The welfare state's 'new empowering politics' would consist of four basic pillars 1) a guaranteed minimum income; 2) a basic income for children; 3) state investments into education and human capital formation; and 4) a guaranteed basic pension, which would be aimed at, on the one hand, increasing each individual's human capital, and on the other hand, favouring the inclusion, coverage, and more equal distribution of risks over the entire life course of the individual [see 
Esping-Andersen and Palier 2008; Hemerijck 2008]. In contrast to the 'old politics of the welfare state', the main goal here would not simply be to help protect citizens from negative effects when markets perform poorly (a poverty alleviation strategy) or to ensure status maintenance under conditions of increasing fiscal constraints (a social reproduction strategy) but rather to separate individuals from the risks associated with more deregulated and less protective and redistributive labour markets while empowering their adaptation to the new knowledge-based society. To put it briefly, through these four main pillars the new empowering politics of the welfare state would: 1) empower through de-commodification; 2) empower through childhood investment; 3) empower through human capital formation; and 4) empower through the rebalancing of life risks.

Alfio Cerami is a research associate at the Centre for European Studies of Sciences Po, Paris. He has also been a visiting lecturer at the University of Erfurt (Germany), at Sciences Po Paris, and at the Centre for German and European Studies of the State University of St. Petersburg (Russia). His most recent publications include Social Policy in Central and Eastern Europe. The Emergence of a New European Welfare Regime (2006, Berlin: LIT Verlag) and Promoting Human Security: Ethical, Normative and Educational Frameworks in Western Europe (together with P. Burgess, et al., 2007, Paris: UNESCO).

\section{References}

Armingeon, K. and G. Bonoli (eds.). 2006. The Politics of Postindustrial Welfare States. Adapting Post-War Social Policies to New Social Risks. London and New York: Routledge.

Atkinson, Anthony. 2002. 'How Basic Income is Moving Up the Policy Agenda: News from the Future.' Paper given at the Ninth Congress of the Basic Income European Network, Geneva 12-14 September.

Böhnke, Petra. 2005. First European Quality of Life Survey: Life Satisfaction, Happiness and Sense of Belonging. European Foundation for the Improving of Living and Working Condition. Luxembourg: Office for Official Publications of the European Communities.

Bonoli, Giuliano. 2007. 'The Political Mobilisation of New Social Risk Groups.' Paper given at the state of the art conference of the RECWOWE Network of Excellence, Warsaw, 12-16 June.

Bourdieu, Pierre. 1983. 'The Forms of Capital.' Pp. 44-67 in Handbook of Theory and Research in the Sociology of Education, edited by John G. Richardson. Westport, CT: Greenwood.

Breen, R. and J. H. Goldthorpe. 1999. 'Class Inequality and Meritocracy: A Critique of Saunders and an Alternative Analysis.' British Journal of Sociology 50: 1-27.

Cerami, Alfio. 2006. Social Policy in Central and Eastern Europe. The Emergence of a New European Welfare Regime. Berlin: LIT Verlag.

Cerami, Alfio. 2009. 'Welfare State Developments in the Russian Federation: 
Oil-Led Social Policy and the "Russian Miracle".' Social Policy \& Administration 43: (forthcoming).

Directorate General Employment and Social Affairs. 2007. Employment in Europe 2007. Brussels: DG Employment and Social Affairs.

Domański, Henryk. 2005. 'The Polish Transformation. Structural Changes and New Tensions.' European Journal of Social Theory 8: 453-470.

Esping-Andersen, G. and B. Palier 2008. Trois Leçons sur l'État-Providence. Paris: Seuil. Esping-Andersen, G., D. Gallie, A. Hemerijck and J. Myles. 2002. Why We Need a New Welfare State. Oxford: Oxford University Press.

Esping-Andersen, Gøsta. 1990. The Three Worlds of Welfare Capitalism. Cambridge: Polity Press.

Esping-Andersen, Gøsta. 1999. The Social Foundations of Postindustrial Economies. Oxford: Oxford University Press.

Esping-Andersen, Gøsta. 2007. 'Sociological Explanations of Changing Income Distributions.' American Behavioral Scientist 50: 639-658.

Esping-Andersen, Gøsta. 2008. 'Childhood Investments and Skill Formation.' International Tax and Public Finance 15: 19-44.

Estevez-Abe, M., T. Iversen and D. Soskice. 2001. 'Social Protection and the Formation of Skills: A Reinterpretation of the Welfare State.' Pp. 145-183 in Varieties of Capitalism. The Institutional Foundations of Comparative Advantage, edited by Peter A. Hall and David Soskice. New York: Oxford University Press.

European Commission. 2006. The Gender Pay Gap - Origins and Policy Responses. A Comparative Review of 30 European Countries. Group of experts on Gender, Social Inclusion and Employment. Brussels: Directorate-General for Employment, Social Affairs and Equal Opportunities.

Eurostat. 2006. Population Statistics. Luxembourg: Office for Official Publications of the European Communities.

Eurostat. 2008. Long-Term Indicators and Structural Indicators. Retrieved 4 December 2008 (http://epp.eurostat.ec.europa.eu/).

Eyal, G., I. Szelényi and E. Townsley. 1998. Making Capitalism without Capitalists: The New Ruling Elites in Eastern Europe. London-New York: Verso.

Fahey, T., C. T. Whelean and B. Maître. 2005. First European Quality of Life Survey: Income Inequality and Deprivation. European Foundation for the Improving of Living and Working Condition. Office for Official Publications of the European Communities, Luxembourg.

Ferrera, M., A. Hemerijck and M. Rhodes. 2000. The Future of Social Europe. Recasting Work and Welfare in the New Economy. Oeiras: Celta Editora.

György, L. and P. Róbert. 2003. 'Middle Classes in the Making in Central and Eastern Europe.' Pp. 99-132 in Inequality and Social Structure during Transition, edited by Vladimir Mikhalev. New York: Palgrave Macmillan.

Hall, P. A. and D. Soskice (eds.). 2001. Varieties of Capitalism. The Institutional Foundations of Comparative Advantage. Oxford University Press: New York.

Häusermann, S. and B. Palier. 2007. 'RECWOWE State of the Art-Report Strand 4: Towards Employment-Friendly Welfare States?' Paper given at the state of the art conference of the RECWOWE Network of Excellence, Warsaw, 12-16 June 2007.

Heckman J. and A. Krueger (eds.). 2003. Inequality in America: What Role for Human Capital Policy. Cambridge, MA: MIT Press.

Hemerijck, Anton. 2008. 'Welfare Recalibration as Social Learning.' Paper given at the ESPAnet Doctoral Researcher Workshop 'The Politics of Recalibration: Welfare Reforms in the Wider Europe', 5-7 June 2008. University of Bologna, Bologna, Italy. 
Hinrichs, Karl. 2008. 'When Political Risks and New Social Risks Coincide: Will Pension Reforms and Increasing Labour Market Flexibility Bring Back Old-Age Poverty in Germany?' Paper given at the 6th Annual ESPAnet Conference, Cross-Border Influences in Social Policy, Helsinki, Finland, 18-20 September 2008.

Iversen, T. and J. D. Stephens. 2008. 'Partisan Politics, the Welfare State, and Three Worlds of Human Capital Formation.' Comparative Political Studies 41 (4/5): 600-637.

Iversen, Torben. 2005. Capitalism, Democracy, and Welfare Cambridge. New York: University Press.

Keller, J. 2005. 'The Czech Republic. Fifteen Years Later.' European Journal of Social Theory 8: $471-485$.

Kitschelt, H. and P. Rehm. 2006. 'New Social Risk and Political Preferences.' Pp. 52-82 in The Politics of Postindustrial Welfare States. Adapting Post-War Social Policies to New Social Risks, edited by K. Armingeon and G. Bonoli. London and New York: Routledge.

Kornai, J. 1992. The Socialist System. The Political Economy of Communism. Princeton, New Jersey: Princeton University Press.

Kwak, A. and G. Pascall. 2005. Gender Regimes in Transition in Central And Eastern Europe. Bristol: Policy Press.

Lascoumes, P. and P. Le Galès. 2007. 'Special Issue: Understanding Public Policy through Its Instruments.' Governance: An International Journal of Policy, Administration, and Institutions 20: 1-21.

Liddle, R. and F. Lerais. 2007. Europe's Social Reality. A Consultation Paper from the Bureau of European Policy Advisers. Brussels: Bureau of European Policy Advisers.

Linz, J. and A. Stepan. 1996. Problems of Democratic Transition and Consolidation: Southern Europe, South America, and Post-Communist Europe. Baltimore: Johns Hopkins University Press.

Luxembourg Income Study (LIS). 2008. Index of Key Figures. Retrieved 4 December 2008 (http://www.lisproject.org/keyfigures/).

OECD. 2008. Growing Unequal? Income Distribution and Poverty in OECD Countries. Paris: OECD.

Orloff, A. S. 2006. 'From Maternalism to "Employment for All": State Policies to Promote Women's Employment across the Affluent Democracies.' Pp. 230-268 in The State After Statism, edited by Jonah Levy. Cambridge, MA: Harvard University Press.

Ost, David. 2005. The Defeat of Solidarity: Anger and Politics in Postcommunism. Cornell: Cornell University Press.

Pierson, P. (ed.) 2001. The New Politics of the Welfare State. Oxford and New York: Oxford University Press.

Profit. 2005a. European Studies on Equalities and Social Cohesion 1/2005. Lodz: Lodz University Press. PROFIT

Profit. 2005b. European Studies on Equalities and Social Cohesion 2/2005. Lodz: Lodz University Press.

Schmidt, Vivien A. 2008. 'Discursive Institutionalism: The Explanatory Power of Ideas and Discourse.' Annual Review of Political Science 11: 303-326

Sirovátka, Tomáš. 2006. 'The Policy of Labour Market and Social Inclusion.' Pp. 185-206 in The Challenge of Social Inclusion. Minorities and Marginalised Groups in Czech Society, edited by T. Sirovátka, E Hamar, K. Klíčová, M. Mareš, P. Navrátil, R. Sedláková, M. Strmiska, C. Szaló, I. Š. Bimíková and I. Vašečka. Brno: Barrister and Principal.

Sirovátka, T. and P. Mareš. 2008. 'Social Exclusion and Forms of Social Capital: Czech Evidence and Mutual Links.' Sociologický časopis/Czech Sociological Review 44: 531-555.

Taylor-Gooby, P. (ed.) 2004. New Risks, New Welfare. The Transformation of the European Welfare State. Oxford: Oxford University Press. 
Vanhuysse, Pieter. 2006. Divide and Pacify. Strategic Social Policies and Political Protests in Post-Communist Democracies. Budapest: CEU Press.

Vanhuysse, Pieter. 2007. 'Workers without Power: Agency, Legacies, and Labour Decline in East European Varieties of Capitalism.' Sociologický časopis/Czech Sociological Review 43 (3): 495-522.

Vanhuysse, Pieter. 2008a. 'Review Article: The New Political Economy of Skill Formation.' Public Administration Review 68 (5): 955-959.

Vanhuysse, Pieter. 2008b. 'Kneeling at the Altar of (Il-)liberalism: The Politics of Ideas, Job Loss and Union Weakness in East Central Europe.' International Labor and Working-Class History 73: 137-151.

World Bank. 2005. Growth, Poverty and Inequality. Eastern Europe and the Former Soviet Union. Washington D.C.: World Bank. 


\title{
The Environmentally Friendly Lifestyle: Simple or Complicated?*
}

\author{
HANA LIBROVÁ** \\ Masaryk University, Brno
}

\begin{abstract}
Simplicity is generally considered an important characteristic of the environmentally friendly lifestyle. This article questions this tenet. Nine dimensions of simplicity are proposed: non-ownership, lack of power, aesthetics, behaviour, naturalness, freedom of movement, the sedentary life/faithfulness to a place, education, and living lightly. Using these categories, the question is asked whether the cultural stereotype of simplicity corresponds to reality. The images of the environmentally friendly lifestyles are analysed from an everyday perspective, including radical forms of self-sufficiency. The result is a conclusion contrary to the common belief: while the life of the typical consumerist is simple, the life of environmental virtue is complex. This finding directs attention to one part of N. Elias' sociological theory, which understands the civilisation process as the replacement of simple behaviour with complex rituals.

Keywords: environmentally friendly lifestyle, voluntary simplicity, nine dimensions of simplicity, self-sufficiency

Sociologický časopis/Czech Sociological Review, 2008, Vol. 44, No. 6: 1111-1128
\end{abstract}

\section{An alternative, or a post-modern dream?}

When we read books advocating ecologically friendly lifestyles or peruse environmental journals, we soon notice that some words recur often. For example, the word 'simple', which is used especially in the expression 'voluntary simplicity', a term coined by Richard B. Gregg, a British disciple of Mahatma Gandhi, in the essay The Value of Voluntary Simplicity [1936]. 'Simplicity' is such an important word in the environmental context that authors even place it in the titles of their books,

\footnotetext{
* The article is based on one chapter of Hana Librová's book 'The Half-hearted and the Hesitant: Chapters on Ecological Luxury', published in 2003 by Doplněk Publishers, Brno, Czech Republic. It was translated by Renata and Benjamin Vail. The article was prepared with the support of the Grant Agency of the Czech Republic under project no. 403/07/0804, 'Individualisation of Lifestyles in an Environmental Perspective'. The author would like to thank Lukáš Kala, an MA student in Environmental Humanities, for his technical help with manuscript preparation.

** Direct all correspondence to: Hana Librová, Department of Environmental Studies, Faculty of Social Studies, Masaryk University, Brno, Czech Republic, e-mail: librova@fss. muni.cz.
} 